\title{
LIST OF MAPS AND FIGURES
}

Map 1: North Syria and Mesopotamia

Map 2: Settlements on the Tưur 'Abdīn plateau

Map 3: Archaeological Surveys of the Khabur Basin

Fig.1: CORONA photograph of Sīrwān

Fig. 2: Aerial image of Nusaybin

All five were created by Kyle Brunner (Institute for Study of the Ancient World, NYU) 
